\title{
Turkish Language Courses Taught in from the Perspective of Turkish-German Relations
}

\author{
Mustafa ÇakıriD, München
}

doi https://dx.doi.org/10.37583/diyalog.958519

\begin{abstract}
The relations between Turkey and Germany have a long history that involves collaboration and partnership in many areas. After 1960s, this relationship gained a new dimension as hundreds of thousands of Turkish workers immigrated to Germany. This paper presents a brief history of the relations between the two countries, and the cultural and language-related problems experienced by Turkish people in Germany. More specifically, it focuses on the background and current state of the Turkish Language and Culture course taught to the Turkish youth in German schools. Problems regarding the implementation of this course are discussed with reference to official statistics. Finally, suggestions are offered to address the challenges faced to improve the Turkish Language and Culture course so that Turkish children can successfully learn their origin-language, and eventually achieve competence in both Turkish and German in their academic studies.
\end{abstract}

Keywords: Turkish-German relations, Turkish immigrants, First language education, Turkish Language and Culture course.

$\ddot{O} z$

Türk Alman İlişkileri ve Almanya'da Verilen Türkçe Dersleri

Türkiye ve Almanya arasındaki ilişkilerin birçok alanda işbirliği ve ortaklık içeren uzun bir tarihi vardır. Bu ilişki, 1960'lı yıllardan sonra yüzbinlerce Türk işçinin Almanya'ya göç etmesiyle yeni bir boyut kazanmıştır. Bu çalışma iki ülke arasındaki ilişkilerin kısa bir tarihini sunarken Almanya'da yaşayan Türklerin deneyimlediği kültür ve dil sorunlarını da ele almaktadır. Çalışmanın ana odak noktası ise Alman okullarında okutulan Türkçe ve Türk Kültürü dersinin geçmişi ve mevcut durumunun incelenmesidir. $\mathrm{Bu}$ dersin yürütülmesinde karşılaşılan sorunlar resmi istatistiklere atıfta bulunularak tartışılmıştır. Son olarak, Almanya'da yaşayan Türk çocuklarının köken dillerini iyi bir düzeyde öğrenebilmeleri ve akademik hayatlarında daha başarılı olmaları adına hem Türkçe hem de Almancada yeterlilik kazanabilmeleri için Türkçe ve Türk Kültürü dersinin geliştirilmesinde karşı karşıya kalınan zorlukların aşılmasına yönelik olarak öneriler sunulmuştur.

Anahtar Sözcükler: Türk-Alman ilişkileri, Türk göçmenler, Ana dil eğitimi, Türkçe ve Türk Kültürü dersi. 


\section{EXTENDED ABSTRACT}

Die Geschichte des Türkischunterrichts in Deutschland lässt sich Hunderte von Jahren zurückverfolgen. Für Deutsche wurden verschiedene Lehrbücher zum Unterrichten von Türkisch als Fremdsprache geschrieben. Die ersten Werke wurden von Kriegsgefangenen und Freigelassenen, Kaufleuten und Missionaren geschrieben. Der Anfang des 19. Jahrhunderts verfasste "Codex Cumanicus" ist das erste türkische Lehrbuch. Neben den turkologischen Fakultäten und Fremdsprachenzentren an Universitäten in der Bundesrepublik Deutschland lassen sich Türkischkurse auch im Primar- und Sekundarbereich in zwei Hauptkategorien einschätzen: Erstens Türkisch als Fremdsprache und zweitens Türkisch als Muttersprachenunterricht (Herkunftssprache, türkische Sprache und türkische Kultur bzw. Landeskunde).

Nach den Suchergebnissen des von der Bundesrektorenkonferenz erstellten Hochschulatlas; An 19 verschiedenen Universitäten des Landes gibt es Lehrangebote für Turkologie auf Bachelor- oder Master-Niveau. In Deutschland werden neben den hier genannten Fachbereichen Türkisch als Fremdsprachenkurse im Fremdsprachenzentrum oder in den Fachbereichen Moderne Fremdsprachen vieler Hochschulen angeboten. Türkisch wird so wie Englisch, Französisch, Chinesisch, Spanisch usw. angeboten. Es kann mit einem "Sprachkurs"-Status geöffnet werden, nicht als nach EU-Normen mit ECTS akkreditiertem Lehrangebot. Anträge auf Eröffnung des Lehrangebots als Fremdsprachenkurs mit ECTS-Punkten werden mit der Begründung zuruckgewiesen, dass es für das Türkisch als Fremdsprache keine internationale Standardprüfung für Sprachstandsanalyse gibt.

Innerhalb des deutschen Schulsystems ist es möglich, Türkisch als Fremdsprache auch an Mittelschulen, Realschulen und Gymnasien außerhalb der Grundschule anzubieten. In Schulen wie der Haupt- oder Mittelschule in Bayern z.B. kann Türkisch am Ende der 9. Klasse in der Qaliprüfung als Fremdsprache gewählt werden. Dafür sollte der Schüler die Schulleitung beantragen; Um die Prüfung erfolgreich $\mathrm{zu}$ bestehen, müssen sie den angebotenen Türkisch- und Türkische Kulturkurs besucht haben. Da diese beiden Bedingungen nicht erfüllt sind, können Studierende dieses Recht nicht in Anspruch nehmen. An Realschulen ist es möglich, anstelle des zweiten Fremdsprachenkurses Französisch nach Englisch in der Wahlpflichtkursgruppe von der 7. Klasse bis zur 9. Klasse auf Antrag von Eltern einen zweiten Fremdsprachenkurs Türkisch anzubieten. Dazu muss der Eltern-LehrerVerband die Zuweisung von Lehrkräften bei der Schulleitung beantragen. Obwohl diese Situation im lokalen Schulgesetz verankert ist, werden in diesen Schulformen keine Türkischkurse angeboten, da die Bürger Französisch als zweite Fremdsprache bevorzugen oder an den Treffen des Eltern-Lehrer-Vereins bzw. Elterntreffen nicht teilnehmen und dies von Schulverwaltungen nicht fordern.

In der Bundesrepublik Deutschland leben etwa 580.000 Kinder türkeistämmiger Herkunft. Auf der anderen Seite arbeiten 503 Lehrer unter den Konsulaten. Die Teilnahme am Unterricht für Türkisch und Türkische Kultur ist freiwillig, kostenlos und es muss von den Eltern mit einem Antrag gefordert werden, damit der Unterricht 
eröffnet und der bestehende Unterricht fortgesetzt werden kann. Der Unterricht für Türkisch und türkische Kultur findet in den öffentlichen Schulen in der Regel nach dem regulären Unterricht oder während der freien Stunden statt. Es wird auf Wunsch von 12 Schülern geöffnet. Der Unterricht findet in der Praxis 2 Stunden pro Woche statt; Sie hat keinen Einfluss auf das Bestehen der Klasse und wird in der Regel nicht mit einer versetzungsrelevanten Note bewertet. In einigen Bundesländern, wie beispielsweise Bayern, können in Zusammenarbeit mit den Schulverwaltungen die Lehrkräfte in den Zeugnissen der Schüler die Teilnahme vermerken oder eine gesonderte „Teilnahmebescheinigung” ausgestellt.

Der Unterricht Türkisch und türkische Kultur bzw. Landeskunde wird in den Schulen, an denen die Schüler teilnehmen, völlig kostenlos angeboten, hauptsächlich in Form von Kulturarbeit im Rahmen des normalen Unterrichtsplans der Schüler in der Zeit außerhalb der aktiven Unterrichtszeit. Ziel des Unterrichts ist es, die Kommunikationsfähigkeiten und die unterschiedlichen Sprachswierigkeiten der Lernenden sowohl in der gesprochenen als auch in der geschriebenen Sprache zu verbessern und $\mathrm{zu}$ entwickeln. Eingeschlossen sind Aktivitäten in den Bereichen "Hören", Sprechen", Lesen-Verstehen, "Schreiben", "Grammatik" und "Landeskunde", die zu den Kompetenzbereichen des Kurses gehören.

Es wird im Sinne der Nachhaltigkeit nicht als ausreichend erachtet, dass türkische Kinder ihre Muttersprache mit den derzeit angebotenen Herkunftssprachkursen (Türkisch und Türkische Kultur) grundsätzlich lernen. Aus diesem Grund können Studien durchgeführt werden, um Curricula zu entwickeln, die für bilinguale Lernumgebungen geeignet sind und deren Inhalte nach lokalen und regionalen Gegebenheiten zusammengestellt werden.

Als Fazit; Wenn die Ursachen von Problemen im akademischen oder diplomatischen Bereich im Zusammenhang mit den Problemen von Staatsbürgern im Ausland übersehen werden und Lösungen versucht werden, sich nur auf die Ergebnisse $\mathrm{zu}$ konzentrieren, ist die erarbeitete Lösung nicht nachhaltig, sondern führt die Mitarbeiter in einen Teufelskreis. Mittel- und langfristig werden neue Probleme nicht zu vermeiden. Wird hingegen die Energie- und Ressourcenverschwendung mit alltäglichen Aktivitäten aufgegeben, die der Öffentlichkeit Sichtbarkeit verschaffen und dazu dienen, mittlere Manager in den Augen der Bürger populär erscheinen zu lassen, entstehen neue und mögliche Probleme. Die diplomatischen mittel- und langfristig zu erwartenden Krisen werden erst dann bewältigt, wenn die direkten Probleme und ihre Ursachen entsprechend dem strategischen Planungsansatz untersucht werden. Es leichter zu handhaben und die gewünschten ergebnisse leichter zu erzielen sind die neuen Feldstudien nötig ${ }^{1}$.

\footnotetext{
${ }^{1}$ Diese Studie entstand aus der Studie Deutsch-Türkische Beziehungen und der Türkischunterricht in Deutschland zum 60. Jahrestag des am 30. Oktober 1961 in Bad Godesberg unterzeichnete Anwerbeabkommen zwischen der Bundesrepublik Deutschland und der Türkei der Migration.
} 


\section{Introduction}

Germany is structured as a federal state. Within this structure, both 16 different states and the central government have their areas of special authority in the country. States are independent in domestic security, education, higher education, culture and local government (Auswärtiges Amt 2018: 7). State government enforce their own law along with the federal law legislated by the central government. Therefore, when it comes to an issue such as education in which German state governments have authority according to their domestic regulations, it would not be possible to conduct a general evaluation for the whole country. In the present study, an essential outline of education in Germany is thus presented. It is thought that it will be useful if readers also refer to the works cited in the references and search for new resources accordingly to gain in-depth knowledge on this issue.

The Federal Republic of Germany demonstrate the current political functionalities of a past that reflects a decentralised cultural and economic structure of the country through states and allows for the representation of different regional identities. After the World War II, the country attained its internationally-recognised constitutional identity in 1949, and in 1990 gained its current structure through the unification of the former East Germany (German Democratic Republic) and West Germany (Federal Republic of Germany). It is notable that the state of Saarland has a history that is quite similar to Hatay province joining the Republic of Turkey later, and joined the Federal Republic of Germany afterwards on the first of January, 1957, when it was a semi-independent state under the aegis of France after the World War II.

According to the data (dated 30 September 2021) of the Federal Statistical Office of Germany, Destatis, the demographical structure of the country consists of nearly 83.2 million people, of whom 41 million are male and 42 million are female. Of this population, 72.650.269 are German while the rest are foreign nationals. The average life expectancy is 78 years in men and 83 years in women. People aged between $70-80$ constitute 7.6 million individuals of the total population.

Germany can be regarded as a country of immigration, considering the fact that $1,120,000$ immigrants came in the first 11 months of 2020, while 897,000 people left the country. The immigrant population is 21.2 million in Germany where one out of every four people is considered to have an immigrant background. Of this population, 128,900 people have acquired German citizenship, and according to the Central Register of Foreign Nationals (Ausländer-Zentralregister (AZR)), 11.2 million people are of foreign nationals. This rate corresponds to $26 \%$ of the total population.

The number of citizens holding Turkish citizenship in the country is $1,472,390$, and 68,620 are under 20 years old and the average age has been recorded as 46.1. In addition, the number of Turkish immigrants who became German citizens in 2019 was 16,235 , and had an average age of 28.7. The number of people with a Turkish descent is $2,038,131$ in the country. In the table below, information regarding the distribution of Turkish people living in the country and the citizens of other major countries are presented in terms of total population and age ranges. 


\begin{tabular}{|c|c|c|c|c|c|c|}
\hline \multirow{2}{*}{ Countries } & \multirow{2}{*}{ Total } & \multicolumn{4}{|c|}{ Distribution of Population by Age } & \multirow{2}{*}{$\begin{array}{l}\text { Average } \\
\text { Age }\end{array}$} \\
\hline & & Under 20 & $20-45$ & 45-65 & Over 65 & \\
\hline Total & 11228300 & 1857165 & $\begin{array}{l}5583 \\
650\end{array}$ & $\begin{array}{l}2764 \\
185\end{array}$ & 1023300 & 37,7 \\
\hline European Total & 7789825 & 986430 & $\begin{array}{l}3676 \\
995\end{array}$ & $\begin{array}{l}2218 \\
920\end{array}$ & 907480 & 40,8 \\
\hline 28 EU Countries Total & 4882495 & 685445 & $\begin{array}{l}2330 \\
820\end{array}$ & $\begin{array}{l}1373 \\
205\end{array}$ & 493025 & 39,7 \\
\hline $\begin{array}{l}\text { EU Candidate Countries } \\
\text { Total }\end{array}$ & 1966755 & 156680 & 894340 & 608415 & 307320 & 44,1 \\
\hline Turkey & 1472390 & 68620 & 658450 & 499100 & 246225 & 46,1 \\
\hline $\begin{array}{l}\text { (Those who became } \\
\text { German in 2019) }\end{array}$ & 16235 & 2440 & 12270 & 1405 & 120 & 28,7 \\
\hline African Total & 600925 & 125035 & 375150 & 83705 & 17035 & 30,5 \\
\hline Americas Total & 296710 & 26315 & 165345 & 78350 & 26700 & 40,1 \\
\hline United States of America & 121645 & 10685 & 51815 & 40145 & 19005 & 44,6 \\
\hline Asian Total & 2408320 & 673915 & $\begin{array}{l}1307 \\
835\end{array}$ & 361110 & 65460 & 29,7 \\
\hline Australia and Oceania & 18345 & 1225 & 11505 & 4040 & 1575 & 39,5 \\
\hline Stateless, Non-nationals & 114170 & 44245 & 46815 & 18055 & 5055 & 27,8 \\
\hline
\end{tabular}

Table 1. Distribution of Foreign Nationals Living in Germany ${ }^{2}$

In Germany, $33.5 \%$ of the population is a high school graduate, $46.6 \%$ has a vocational education and $18.5 \%$ has higher education. More than half of the population aged between 20-24 has a high school degree (i.e. Abitur). On the other hand, the number of academics aged between $30-34$ is twice the previous generation.

\section{Turkish-German Relations from Past to Present}

The history of German-Turkish relations goes back to hundreds of years ago (see Arasli 2009; Gencer 2002; Koçak 1991, Öztürk 2000). Several reasons led Europeans to initiate eight different Crusades to Anatolia between the years 1096-1270: European knights sought for fame, poor Europeans wanted to improve their economic situation by acquiring new lands, the Byzantine emperor Alexios I Komnenos asked Pope Urban to send for Europe's help against Turks, and clergymen announced a "Just War" (i.e. bellum iustum in Latin) to obtain holy places like Jerusalem, Antioch. and Alexandria. There were also political reasons including the expulsion of Turks from Anatolia and preventing their transition to the Balkans. The first Turkish-German encounter in history happened when the Anatolian Seljuk Sultan, Kilij Arslan II came across the

\footnotetext{
${ }^{2}$ Destatis, Central Register of Foreign Nationals (Ausländer-Zentralregister (AZR)), April 15, 2020.
} 
German king and Roman emperor, Friedrich I in the Second Crusade. In late 1147, they were defeated by the Anatolian Seljuk, Mesud I near Eskişehir (i.e. 26 October 1147-the second Battle of Dorylaeum). Later, with an agreement between the two sides, the German army was allowed to go to Jerusalem (Çakır 2012: 27). However, the emperor's dream to reach Jerusalem continued only until he reached the Dim Stream in Mersin where he drowned (Alperen 2018: 625). His successor, emperor Conrad III of the Hohennstaufen dynasty came to Anatolia leading the army during the Crusades. Although he battled against the Anatolian Seljuk, Mesud I, friendly relations were also established between the two leaders (see Y1ldırım 2008: 490).

When the Ottoman Empire started to be seen as a new threat to the European countries, the Turkish-German relations resumed. In 1554, during the reign of Suleiman the Magnificent, Cardinal Busbeck worked as the Austrian Ambassador to the Ottoman Empire entrusted with full authority by Karl I. Although the Germans and Ottomans did not come face to face during the Siege of Vienna (1529), it is known that some German principalities supported Austria. The last war in which Turkish and German soldiers fought against each other was the second Siege of Vienna (1683). The Kingdom of Prussia as a military power in the $18^{\text {th }}$ century sided with the Ottoman Empire against the Russians and Austrians. Being aware of this support, the Ottoman Empire became the first state to congratulate the Prussian King Friedrich, leading to a visit by Asim Efendi to Berlin and then King Friedrich's sending Johannes Jorgowsky to Istanbul in 1721 (see Muhtar, 1999); thus, a mutual official relationship was established between the two countries.

Ferdinand II who ascended the throne in 1740 appointed count Carlo E. Rexin as an ambassador to Istanbul. A "Peace and Amity Treaty" was signed between the Kingdom of Prussia and Ottoman Empire represented by Grand Vizer Koca Ragip Pasha and count Carlo E. Rexin; based on this treaty, Ahmet Resmi Efendi was assigned as an ambassador to Berlin. Then, his son and successor, Wilhelm I also continued to have close ties with the Ottoman Empire for strategic reasons (see Özakınc1 2007). This treaty was renewed by Selim III in 1790.

The trade relations between the Ottoman Empire and the Germans started with the Trade Agreement signed in 1840. Research studies on Anatolia were conducted through the German Oriental Society (Deutsche Morgenländische Gesellschaft -DMG) established in Darmstadt on 2 October 1845 to research and disseminate information about the languages and cultures of the East, Asia, Oceania and Africa. The employees of this society received special permission to carry out archaeological excavations in Turkey; Archaeologist Heinrich Schliemann carried the Trojan treasures, and engineer Karl Humann carried the Zeus Temple in the Pergamon Acropolis to Berlin (Önder 1983). The Baghdad Rail Line Project was implemented through the Anatolian Railways Company, which was established with the Turkish-German partnership in 1898; German schools and hospitals were opened; many students have been sent to Germany to study. In 1913, there were 1301 Turkish people studying in Germany and working in a tobacco factory. They used to publish a magazine titled Neue Türkei (New Turkey) in Berlin (see Çolak 2014). 
The importance that Sultan Abdülhamit attributed to the relations between the two countries was maintained by the Union and Progress Party with the Constitutional Monarchy. Prior to the World War I (1914-1918), Edward VII, the King of the United Kingdom, and the Russian Emperor, Nikola II held a meeting in today's Estonian capital, Tallinn (i.e. Reval) located in the Balctic coast of the Gulf of Finland on 9 June 1908. The fact that the Germans were not invited to this meeting reinforced the TurkishGerman friendship (Ar1 1997). During the World War I, German warships Goeben and Breslau that were escaping from the British and French navies crossed the Dardanelles and entered the Marmara Sea on 10 August 1914 with the permission of the Deputy Commander-in-Chief of War, Enver Pasha. Although the ships were adopted by naming Goeben as Yavuz and Breslau as Midilli (Bayur 1983: 161), these two ships bombarded Russian ports on 29 October 1914. Afterwards, Russia declared war and the Ottoman Empire was suddenly landed in the middle of the war. Thus, Britain and France declared war on the Ottoman Empire by taking side with their ally, Russia. Entering the war alongside the Germans in November 1914, the Ottoman Empire handed over its army to German General Liman von Sanders at the very beginning, and therefore had to fight on many fronts such as Çanakkale, Palestine and Syria.

Wilhelm II visited Istanbul for the third time in 1917, and the Ottoman crown prince, Vahdettin, paid a return visit the same year. Mustafa Kemal who was the commander of the First Army appeared in the delegation as the "army representative". Diplomatic relations were interrupted by the Armistice of Mudanya on 30 October 1918, and the diplomatic relations were reinstated through a Friendship Treaty (3 March 1924) between the new Republic of Turkey founded following the War of Independence, and Germany. In the period until the World War II, a Consular Agreement (1929) and a Trade Agreement (1930) were signed.

Turkey that insisted not to go into the World War II until 2 August 1944 accepted distinguished scientists from Germany starting from 1933 and employed them in universities. This brought about important contributions "in structuring of our universities, resurrecting our arts and cultural life in accordance with Western norms, the establishment of major industrial facilities, and areas such as urban planning and municipal work." (Y1ldırım 2008: 492).

The German language became widely spoken among Turkish scientists. The diplomatic relations were disrupted due to Turkey's taking side against Germany in the World War II. The state of war between the two countries ended by means of a law legislated at the Turkish Grand National Assembly on 24 July 1951 after the war, followed by the reinstatement of the diplomatic relations when the German side was notified about the law.

Germany and Turkey signed the "Agreement on the Recruitment of Turkish Workers in the Federal Republic of Germany" on 20 October 1961, which took the relations to a new stage. 


\section{Foreign Labour Employment in Germany}

Germany has evolved into a multinational and multicultural demographic structure that receives more and more immigrants in recent years. In some settlements, more than $50 \%$ of the population is of immigrant background. Therefore, the current identity does not overlap with the traditional German identity in history, and values are also changing and transforming with the demographic structure. As Hermann Bahr noted in his diary (23 October 1923), almost everyone tries to rebuild a German identity and there is uncertainty about who to call a German (Borchmeyer 2017: 13).

After the World War II, Germany decided to tackle the labour shortage required to restructure the country with foreign workers. Labour agreements were signed first with Italy in 1955 and then with Spain and Greece in 1960. Despite this, the labour shortage could not be resolved. Afterwards, agreements were finalised with Turkey (1961), Morocco (1963), Portugal (1964), Tunisia (1965) and Yugoslavia (1968) (Koçtürk 2008; Bacınoğl and Bacınoğl 2001; Unver 2015).

The labour agreement between the Republic of Turkey and the Federal Republic of Germany entered into force for one year starting from 1 September 1961 with the acceptance of the note of the Federal Republic of Germany (dated 30 October 1961 and no. 505-83 SZV/3-92-42) offering to place unemployed Turkish citizens to a job through German employers (Tuna 2011). In a meeting between the delegations held in Bonn on 19 May 1964, discussions were made on the issues that emerged in practice, and additional articles were added to the agreement (Çakır 2019a: 95). A social security agreement was signed between the two countries on 30 April 1964. Based on these agreements, the number of Turkish workers who went to Germany reached nearly hundreds of thousands of people. Recruiting workers from Turkey has been officially stopped in 1973 because of the world oil crisis and economic difficulties. However, due to family reunification, the number of Turkish citizens in Germany reached up to 1.8 million. Germany started applying radical measures, and obliged Turkish citizens to obtain visas in 1980. In family reunification, the age limit for the family members coming from Turkey was reduced to 16 (Kaya 2000: 59). Moreover, a law was enacted on 28 November 1983 to encourage return. Germany provided monetary aids to workers who decided to return Turkey between 31 October 1983 - 30 June 1984, and paid them $10,500 \mathrm{DM}$ on top of 1,500 DM per child. After returning to Turkey, workers were paid back their retirement cuts they paid during the time they worked in Germany, adaptation courses were opened in Turkey for children of workers' families to adapt to the life in Turkey, and a bilateral agreement was signed with Turkey in 1984 to manage this process (see Kaya 2009). In addition, while the "Law on Foreigners", which entered into force on 1 January 1991, facilitated the transition to German citizenship, it also brought along restrictive provisions on unemployment. Eventually at this point, every Turkish child born in Germany is given German citizenship, and the Turkish-origin German citizens in the country are not evaluated in the statistics as they are shown as German citizens in the negotiations between the two countries. Immigration from Turkey to Germany continue both legally and illegally, and this immigration is reflected in all areas of societal and social life. 


\section{Education of Workers' Children}

The education system in the Federal Republic of Germany was developed in a liberal structure between the years 1770-1830, and today the bourgeois acts based on an educational understanding at the first and top sections of the society. This structure has been transforming with foreigners coming to the country, and empirical studies conducted for the past two decades have found that the school achievement of immigrant children is lower than their German peers (see Hopf 1981; Reiser 1981; Esser 1990; Alba et al. 1994; Büchel and Wagner 1996). In the 2006-2007 school year, $9,355,857$ students study in schools providing general education in the country, and the rate of foreign students is $9.7 \%$. The largest group of foreign students are those carrying Turkish passports (42.7\% male and $40.3 \%$ female). The second and third largest groups consist of Italian and Serbian-Montenegrin students, respectively (Siegert 2008: 18).

\begin{tabular}{|l|l|l|l|l|l|l|l|}
\hline STATES & $\begin{array}{l}\text { Primary } \\
\text { school }\end{array}$ & $\begin{array}{l}\text { Middle } \\
\text { School }\end{array}$ & $\begin{array}{l}\text { High } \\
\text { school }\end{array}$ & $\begin{array}{l}\text { Vocation } \\
\text { al high } \\
\text { school / } \\
\text { school }\end{array}$ & Other & Total & $\begin{array}{l}\text { Approximate } \\
\text { Turkish } \\
\text { Population }\end{array}$ \\
\hline Berlin & 2,534 & 2,954 & 1,637 & 2,425 & 254 & 9,804 & 267,180 \\
\hline $\begin{array}{l}\text { Baden } \\
\text { Württemberg }\end{array}$ & 4,227 & 9,685 & 2,422 & 18,400 & 1,567 & 36,301 & 262,094 \\
\hline Lower Saxony & 16,120 & - & 18,516 & 4,812 & - & 39,448 & 95,740 \\
\hline Bremen & 1,999 & - & 542 & 1,389 & - & 3,930 & 25,575 \\
\hline Saxony-Anhalt & 128 & - & 29 & 30 & - & 187 & 2,207 \\
\hline Bavaria & 2,235 & 5,690 & 1,611 & 11,209 & 686 & 21,431 & 420,000 \\
\hline $\begin{array}{l}\text { Rhineland- } \\
\text { Palatinate }\end{array}$ & 1,035 & 2,272 & 503 & 4,326 & 218 & 8,354 & 62,419 \\
\hline Saarland & 559 & 451 & 118 & 603 & 52 & 1,783 & 11,830 \\
\hline Hamburg & 3,224 & 3,389 & 893 & 1,416 & - & 8,922 & 53,038 \\
\hline $\begin{array}{l}\text { Schleswig } \\
\text { Holstein }\end{array}$ & 2,797 & 2,229 & 526 & 730 & - & 6,282 & 32,517 \\
\hline $\begin{array}{l}\text { North Rhine } \\
\text { Westphalia }\end{array}$ & 6,144 & 21,114 & 7,713 & 22,478 & - & 57,449 & 505,531 \\
\hline Hessen & 1,636 & 3,864 & 2,786 & 8,931 & 619 & 17,836 & 300,000 \\
\hline TOTAL & $\mathbf{4 2 , 6 3 8}$ & $\mathbf{5 1 , 6 4 8}$ & $\mathbf{3 7 , 2 9 6}$ & $\mathbf{7 6 , 7 4 9}$ & $\mathbf{3 , 3 9 6}$ & $\mathbf{2 1 1 , 9 8}$ & $\mathbf{4}, \mathbf{2 3 8 , 1 3 1}$ \\
\hline
\end{tabular}

Table 2. Distribution of Turkish Students and Citizens in Germany by School Types and States ${ }^{3}$

As a result of the PISA surveys conducted by the Organisation for Economic Cooperation and Development (OECD) with the participation of 57 countries, it was

\footnotetext{
${ }^{3}$ Education Office, Turkish Embassy in Berlin.
} 
determined that the school success of 15 -year-old students with a foreign or immigrant background in Germany was two years behind their peers. However, in the study conducted in 2018, there was no radical change in this difference compared to the past (see Reiss et al. 2019). The reading comprehension research study, which is known as PIRLS (Progress in International Reading Literacy Study) internationally and as "IGLU" (Internationale Grundschul-Lese-Untersuchung) in Germany, that was conducted on primary school students in the years 2001, 2006, 2011 and 2016 similarly demonstrated that inequality in the German education system still continued based on social strata and immigration factors. German scientists, particularly Gogolin (1995: 481), published studies stating that if the language development levels of immigrant students are improved, their school success will also go up (Fthenakis 1985; Estel 1993; Esser 2006). In her study, Rolffs (2009) made the following observation about Turkish children:

When a child who speaks little German, that is, does not speak it as his/her mother tongue starts school, he/she has to compete with children whose mother tongue is German in terms of success, and is expected to achieve at least the same level as them. This inevitably puts stress on the child who will either win this race doing as best as he/she can, or lose wearily. Statistics clearly show that the overwhelming majority of Turkish-origin children lose this race, and around $25 \%$ of young Turkish people drop out without getting any school diploma. This is not because these children are lazier or retarded; on the contrary, it is due to the fact that the current education system does not provide an environment that will support and facilitate their learning and provide them a setting where they feel good.

This evaluation is thought to be sufficient to explain the school success of Turkish children in the country.

According to the higher education statistics, most of the foreign students in Germany in the fall semester of the 2019/2020 academic year come from China. During this period, a total of 411,601 foreign students were enrolled in German universities. The three largest countries from which foreign students come to Germany to are China, Turkey and India. According to the data of the Federal Statistical Office of Germany, Destatis, approximately 2,891,049 students study at German universities in the fall semester of the 2019/2020 academic year. The proportion of newly enrolled students is $54.8 \%$, and the number of students who are in the field of business administration is 236,952. The preferred areas of study are mainly law, economics and social sciences, followed by engineering and humanities.

\section{Bilingualism and Language Acquisition}

In Germany, many studies were conducted on language learning and second language acquisition of the second generation and naming the subsequent languages. While studies focused mainly on how to define migrant workers (Çakır 1991, 2015) and daily spoken languages (Clyne 1968; Keim 1978, 1981, 1984; Heidelberger Forschungsprojekt 1975; Meisel 1975), over time, they investigated the new generation's language and educational problems (Schwenk 1988). With respect to 
language education, bilingualism and language acquisition have come to the fore in this respect.

The new terms that have emerged with this trend are to be explained in this section. Language learning is the process of raising awareness and acquiring knowledge in the target language in a directed or undirected way in formal settings. Individuals are "conscious" and "willing" in language learning, whereas the "subconscious" process of language is defined in language acquisition. Regarding this process, various theories including the monitor model, input hypothesis and affective filter theory have been proposed (Krashen 1982, 2002; Klein 1992). Detailed information about these theories will not be presented here, but can be accessed from relevant sources.

When language acquisition theories are concerned, the issue of Language Acquisition Device (LAD), which has not been agreed between Chomsky and Krashen, comes to prominence. While Chomsky (2018) states that the language acquisition process is over at the end of childhood, Krashen believes that this process continues in adulthood. According to this theory, Chomsky argues that cognitive learning is effective instead of language acquisition, and language acquisition is not possible for adults, unlike Krashen. Below are the primary differences between language learning and acquisition.

\begin{tabular}{|l|l|}
\hline Language Acquisition & Language Learning \\
\hline similar to a child's first language acquisition & formal grammar is taught \\
\hline 'a language' is acquired naturally & one needs to have a knowledge of a language \\
\hline Subconscious & Conscious \\
\hline implicit knowledge & explicit knowledge \\
\hline formal instruction does not help & formal instruction does help \\
\hline
\end{tabular}

Table 3. Distinctions Between Language Learning and Language Acquisition ${ }^{4}$

Bilingualism is defined as "having two different languages and therefore two separate systems that provide effective communication between two different worlds" (Baziers and von Overbeke, as cited in 1968: 133, Aslan 2020). Bilingualism has been a studied on individual or social/institutional scales (Karaağaç 2011; Bölükbaş-Kaya et al. 2019). Individual bilingualism is defined as additive bilingualism ("additiver Bilingualismus" in German) and subtractive bilingualism ("subtraktiver Bilingualismus" in German). Individuals evaluate their language status socially and economically; if they tend to exclude their own language and culture at this stage, this can be a case of subtractive bilingualism. (Genç 2011). When evaluated in terms of individuals' linguistic competence, bilingualism is addressed in terms of three aspects that are balanced bilingualism, dominant bilingualism and semilingualism (see Uyar 2012).

Studies on bilingualism are grouped based on the time the language is learned/acquired (learning/acquisition of both languages simultaneously or the second language later), learning conditions (learning the second language in a natural

\footnotetext{
${ }^{4}$ Adapted from Krashen/ Terrell 1983: 29.
} 
environment or formal educational institutions), proficiency (equal performance in both languages, in other words, having advanced practice of alternative usage (Weinreich 1968: 1), the second language being dominant over the first language in time) and the relationship between the two languages (the first language being valued in the environment where the second language is spoken) (see Rolffs 2009). In Turkey, studies on bilingualism and the other languages learned afterwards have also increased through translation studies (Yılmaz 2014; Ateşal 2017; Haznedar 2021).

With respect to Turkish people in Germany, bilingualism studies refer to the necessity that individuals need to have equal command over both languages to be defined as bilinguals (Braun 1937). However, Cummins (1982) points out in his interdependence hypothesis (Interdependenz-Hypothese) the importance of language acquisition and transition between languages in the process of bilingual education. The types of bilingualism and its cognitive effect are summarised in Table 4 based on the literature.

\begin{tabular}{|l|l|}
\hline Types of bilingualism & Cognitive effects \\
\hline Additive bilingualism & Positive cognitive effects \\
\hline $\begin{array}{l}\text { Dominant bilingualism } \\
\text { good command of one of the two languages }\end{array}$ & \\
\hline Semilingualism & Neither positive nor negative cognitive effects \\
poor command of both languages & \\
\hline
\end{tabular}

Table 4. Types of Bilingualism and its Cognitive Effects (Appel/ Muysken 1987: 112)

Bekar (2016: 5) reported that languages and cultures of Turkish-speaking people of Turkish origin (i.e. holding Turkish and German citizenship) "are subject to exclusion new generations under the name of harmonization efforts, and new generations are gradually assimilated." Yild1z (2003: 12) found that students are not able to master both languages at the same level, one of the spoken languages is always dominant with the other becoming secondary, and the rate of learning caused differences across environment, family and cultural structure based on ability and intelligence.

\begin{tabular}{|l|c|c|c|c|c|}
\hline & Turkish only & \multicolumn{3}{|c|}{ Turkish and German } & German only \\
\hline & $\begin{array}{l}\text { Dominant } \\
\text { Turkish }\end{array}$ & $\begin{array}{l}\text { Dominant } \\
\text { German }\end{array}$ & $\begin{array}{l}\text { Equal levels of } \\
\text { Turkish and German }\end{array}$ & - \\
\hline $\begin{array}{l}\text { First } \\
\text { generation }\end{array}$ & +++ & +++ & - & + & - \\
\hline $\begin{array}{l}\text { Second } \\
\text { generation }\end{array}$ & ++ & \multicolumn{2}{|c|}{+++} & ++ & + \\
\hline $\begin{array}{l}\text { Third } \\
\text { generation }\end{array}$ & - & + & +++ & ++ & + \\
\hline
\end{tabular}

Table 5. Language Levels of Turkish Students ${ }^{5}$

\footnotetext{
${ }^{5}$ One plus $(+)$ means poor command, two plus $(++)$ intermediate and three plus $(+++)$ good command. Source: Bekar 2015.
} 


\section{Turkish Language Courses in Germany}

Germans are one of the leading nations that learn Turkish as a foreign language for reasons such as missionary, communication, military, politics, education, economy, tourism and immigration (Özbal 2020: 180). Therefore, the history of teaching Turkish in Germany goes back to hundreds of years ago. Textbooks on teaching Turkish as a foreign language were written for Germans. The first works were of those who were taken prisoner in the war and then released, merchants and missionaries. One of these works is "Codex Cumanicus" written by German missionaries in early fourteenth century. Güzel and Barın (2013: 26) state that this work consists of two notebooks; the first notebook is 55 pages long and the second one is 26 pages long. The bibliographic analysis conducted in Özbal's (2020) qualitative research is a guide for those who want to gain extensive information on this work.

Except for the Turkology departments and foreign language centres in universities, Turkish courses at primary and secondary education level in the Federal Republic of Germany can be evaluated under two main groups: the first is Turkish as a foreign language course, and the second is Turkish as a first language (origin language, Turkish and Turkish culture) course.

\section{Turkology Departments and Turkish a Foreign Language Courses at Universities}

According to the data available on the Higher Education Compass (Hochschulkompass: https://www.hochschulkompass.de) created by the German Rectors' Conference (Hochschulrektorenkonferenz), there are 19 Turkology-related departments at undergraduate or graduate level in Germany. These programs and the universities that provide them are listed in Table 6.

\begin{tabular}{|l|l|l|l|l|l|}
\hline Area of Study & University & $\begin{array}{l}\text { Degree of } \\
\text { Completion }\end{array}$ & $\begin{array}{l}\text { Mode of } \\
\text { Education }\end{array}$ & City & Level \\
\hline $\begin{array}{l}\text { Geschichte, Sprachen } \\
\text { und Kulturen des } \\
\text { Vorderen Orients/ } \\
\text { Schwerpunkt } \\
\text { Turkologie }\end{array}$ & $\begin{array}{l}\text { Universität } \\
\text { Hamburg }\end{array}$ & Bachelor & $\begin{array}{l}\text { International } \\
\text { Program, } \\
\text { Part-time, full- } \\
\text { time education }\end{array}$ & Hamburg & Undergraduate \\
\hline $\begin{array}{l}\text { Geschichte u. Kultur } \\
\text { d. Vord. Orients/ } \\
\text { Turkologie }\end{array}$ & $\begin{array}{l}\text { Freie } \\
\text { Universität } \\
\text { Berlin }\end{array}$ & Bachelor & $\begin{array}{l}\text { Full-time } \\
\text { education }\end{array}$ & Berlin & Undergraduate \\
\hline $\begin{array}{l}\text { Turkologie } \\
\text { Otto- } \\
\text { Friedrich- } \\
\text { Universität } \\
\text { Bamberg }\end{array}$ & Master & $\begin{array}{l}\text { Part-time } \\
\text { education, } \\
\text { Full-time } \\
\text { education }\end{array}$ & Bamberg & Graduate \\
\hline Turkologie & $\begin{array}{l}\text { Freie } \\
\text { Universität } \\
\text { Berlin }\end{array}$ & Master & $\begin{array}{l}\text { Full-time } \\
\text { education }\end{array}$ & Berlin & Graduate \\
\hline
\end{tabular}




\begin{tabular}{|c|c|c|c|c|c|}
\hline Turkologie & $\begin{array}{l}\text { Georg- } \\
\text { August- } \\
\text { Universität } \\
\text { Göttingen }\end{array}$ & $\begin{array}{l}\text { Bachelor (2- } \\
\text { Anadal) }\end{array}$ & $\begin{array}{l}\text { Full-time } \\
\text { education }\end{array}$ & Göttingen & Undergraduate \\
\hline Turkologie & $\begin{array}{l}\text { Georg- } \\
\text { August- } \\
\text { Universität } \\
\text { Göttingen }\end{array}$ & Master & $\begin{array}{l}\text { Full-time } \\
\text { education }\end{array}$ & Göttingen & Graduate \\
\hline Turkologie & $\begin{array}{l}\text { Johannes } \\
\text { Gutenberg- } \\
\text { Universität } \\
\text { Mainz }\end{array}$ & $\begin{array}{l}\text { Bachelor of } \\
\text { Arts } \\
\text { (Two } \\
\text { Programs - } \\
\text { Bachelor) }\end{array}$ & $\begin{array}{l}\text { Full-time } \\
\text { education }\end{array}$ & Mainz & Undergraduate \\
\hline $\begin{array}{l}\text { Kulturwissenschaften } \\
\text { des Vorderen Orients } \\
\text { (Elite- } \\
\text { Masterstudiengang) }\end{array}$ & $\begin{array}{l}\text { Otto- } \\
\text { Friedrich- } \\
\text { Universität } \\
\text { Bamberg }\end{array}$ & $\begin{array}{l}\text { Master of } \\
\text { Arts }\end{array}$ & $\begin{array}{l}\text { Part-time } \\
\text { education, } \\
\text { Full-time } \\
\text { education }\end{array}$ & Bamberg & Graduate \\
\hline Linguistik & $\begin{array}{l}\text { Johannes } \\
\text { Gutenberg- } \\
\text { Universität } \\
\text { Mainz }\end{array}$ & $\begin{array}{l}\text { Bachelor of } \\
\text { Arts } \\
\text { (Two } \\
\text { Programs- } \\
\text { Bachelor) }\end{array}$ & $\begin{array}{l}\text { Full-time } \\
\text { education }\end{array}$ & Mainz & Undergraduate \\
\hline Linguistik & $\begin{array}{l}\text { Johannes } \\
\text { Gutenberg- } \\
\text { Universität } \\
\text { Mainz }\end{array}$ & $\begin{array}{l}\text { Master of } \\
\text { Arts }\end{array}$ & $\begin{array}{l}\text { Full-time } \\
\text { education }\end{array}$ & Mainz & Graduate \\
\hline M.A. Nahoststudien & $\begin{array}{l}\text { Hochschule } \\
\text { für Jüdische } \\
\text { Studien } \\
\text { Heidelberg, } \\
\text { Universität } \\
\text { Heidelberg }\end{array}$ & Master & $\begin{array}{l}\text { Full-time } \\
\text { education }\end{array}$ & Heidelberg & Graduate \\
\hline $\begin{array}{l}\text { Naher und Mittlerer } \\
\text { Osten }\end{array}$ & $\begin{array}{l}\text { Ludwig- } \\
\text { Maximilians- } \\
\text { Universität } \\
\text { München }\end{array}$ & $\begin{array}{l}\text { Bachelor of } \\
\text { Arts }\end{array}$ & $\begin{array}{l}\text { Full-time } \\
\text { education }\end{array}$ & München & Undergraduate \\
\hline Nahoststudien & $\begin{array}{l}\text { Ruprecht- } \\
\text { Karls- } \\
\text { Universität } \\
\text { Heidelberg, } \\
\text { Hochschule } \\
\text { für Jüdische } \\
\text { Studien }\end{array}$ & Master & $\begin{array}{l}\text { Full-time } \\
\text { education }\end{array}$ & Heidelberg & Graduate \\
\hline $\begin{array}{lr}\text { Sprachen } & \text { und } \\
\text { Kulturen } & \text { der } \\
\text { islamischen Welt } & \end{array}$ & $\begin{array}{l}\text { Universität } \\
\text { zu Köln }\end{array}$ & $\begin{array}{l}\text { Bachelor of } \\
\text { Arts } \\
\text { (One }\end{array}$ & $\begin{array}{l}\text { Full-time } \\
\text { education }\end{array}$ & Köln & Undergraduate \\
\hline
\end{tabular}




\begin{tabular}{|c|c|c|c|c|c|}
\hline & & Program) & & & \\
\hline $\begin{array}{lr}\text { Sprachen } & \text { und } \\
\text { Kulturen } & \text { der } \\
\text { islamischen Welt } & \end{array}$ & $\begin{array}{l}\text { Universität } \\
\text { zu Köln }\end{array}$ & $\begin{array}{l}\text { Bachelor of } \\
\text { Arts } \\
\text { (2 Anadal) }\end{array}$ & $\begin{array}{l}\text { Full-time } \\
\text { education }\end{array}$ & Köln & Undergraduate \\
\hline Turcology & $\begin{array}{l}\text { Johannes } \\
\text { Gutenberg- } \\
\text { Universität } \\
\text { Mainz }\end{array}$ & $\begin{array}{l}\text { Master of } \\
\text { Arts }\end{array}$ & $\begin{array}{l}\text { Internationaler } \\
\text { Studiengang, } \\
\text { Tam zamanlı } \\
\text { eğitim }\end{array}$ & Mainz & Graduate \\
\hline Türkeistudien & $\begin{array}{l}\text { Universität } \\
\text { Duisburg- } \\
\text { Essen }\end{array}$ & $\begin{array}{l}\text { Bachelor of } \\
\text { Arts } \\
2 \text { Anadal }\end{array}$ & $\begin{array}{l}\text { Full-time } \\
\text { education }\end{array}$ & Essen & Undergraduate \\
\hline Türkisch & $\begin{array}{l}\text { Rheinische } \\
\text { Friedrich- } \\
\text { Wilhelms- } \\
\text { Universität } \\
\text { Bonn }\end{array}$ & Bachelor & $\begin{array}{l}\text { Full-time } \\
\text { education }\end{array}$ & Bonn & Undergraduate \\
\hline
\end{tabular}

Table 6. Turkology Departments in German Universities

Apart from the departments mentioned here, Turkish as a foreign language courses are opened in the Foreign Language Centres or departments of modern foreign languages in many German universities. Turkish language courses can be opened with a "class" status, rather than a credit course like English, French, Chinese and Spanish. Requests for Turkish courses to be opened as a foreign language course with ECTS credits are rejected on the grounds that there is no international standard exam that measures Turkish as a foreign language proficiency. While each of our institutions that aim to teach Turkish as a foreign language (e.g. Turkish Ministry of Education, Ankara University Turkish Teaching Centre, Yunus Emre Institute, Turkish Maarif Foundation) prepares a separate curriculum, they cannot come together and agree on a single program and an internationally valid exam related to this program, which is a subject of another discussion. On the other hand, for German, four countries (i.e. Germany, Austria, Switzerland, Liechtenstein) came together to prepare the Profil deutsch (Globaniat et al. 2012), a single framework program, and they administer exams created based on the language levels in this framework (see Quetz 2010 - GER A1, A2, B1, B2, C1, C2). The Turkish Ministry of National Education became a member of the Association of Language Testers in Europe (ALTE), and initiated a process to administer an internationally recognised and reliable Turkish language test. In this sense, it seems essential that other institutions that teach Turkish language are also accredited by EAQUALS (Evaluation and Accreditation of Quality Language Services), which encourages "achieving excellence in language education through quality accreditation".

According to the Program Atlas (https://yokatlas.yok.gov.tr/) created by the Turkish Council of Higher Education (YÖK), there are three main groups of undergraduate programs on German in Turkey: German Language and Literature, German Translation and Interpreting, and German Language Teaching. The data 
updated in 2020 shows that there are a total of 32 higher education programs in Turkey that contribute to German language and culture including 15 German Language and Literature programs in 13 universities, German Language Teaching programs in 17 universities, and 10 German Translation and Interpreting programs in six universities. Moreover, in all Turkish universities, German courses are opened as compulsory or elective foreign language courses, and these courses are credited in the scope of European Credit Transfer and Accumulation System (ECTS) and affect passing to the next grade/year.

In response to the practice in Germany, the status of the German Language and Literature, and German Language Teaching programs that were opened in Turkish universities without sufficient number of faculty members/instructors should be reconsidered. In addition, the foreign language courses in state schools as well as the student quotas of the German-related programs and the state of German courses in Turkish universities may need to be revised.

\section{Turkish Courses Taught in Primary and Secondary Schools}

Although it is not possible to state a general rule for Germany, apart from Grundschule (primary school), it is possible to open Turkish as a foreign language courses in Mittelschule (secondary school that prepares for and directs towards a vocational education), Realschule (upper secondary school) and Gymnasium (secondary school and high school targeting college, university).

In the type of school like Hauptschule or Mittelschule (secondary school that prepares and guides for a vocational education), for example in Bavaria, Turkish can be selected as a foreign language in the secondary school completion exam (i.e. Qaliprüfung). For this, students must submit a petition to the school administration, and in order to be successful in the exam, they must attend the Turkish Language and Culture Course. Since these two conditions are not fulfilled, students cannot benefit from this right.

In Realschule (upper secondary school), opening Turkish as a foreign language course instead of French beside English in the compulsory electives group from seventh to ninth grades is possible only with the request of school-parents associations. For this, the school-parents association must ask the school administration to find a teacher. However, although this is included in the local legislation, since the citizens prefer French as the second foreign language or they do not attend the meetings of schoolparents associations and do not go after this issue, Turkish as a foreign language courses are not opened in this school level (Realschule).

Turkish as a foreign language courses taught in high schools in Germany show different application models depending on the state as is stated by Çakır (2014 2019a, $2019 \mathrm{~b}$ ) who is an experienced researcher and language teacher trainer. Accordingly, in Gymnasium (middle school and high school towards college or university education), Turkish is taught as an elective foreign language course. Although this course is 
included in the curriculum at A1 level starting from the $10^{\text {th }}$ grade, it is opened at A2 level due to various reasons (e.g. lack of teachers, insufficient applicants) and thus students can enrol for this course through an A2 proficiency test. The course is taught at B1 level in the $12^{\text {th }}$ grade. Students can be tested from this course in the graduation exam (i.e. Abitur) at the end of the $12^{\text {th }}$ grade. For this course to be opened, students need to apply to their school administration and form groups of 12 participants. In schools where these groups cannot be formed, they can take this course from another school where it is offered. Although it does not seem quite realistic for a student studying in one school to go to a school in another district to take Turkish classes only, students who choose the course should be able to reach $\mathrm{C} 1$ level instead of B1 on the grounds that their native language is Turkish. Due to the failure in the graduation exam (Abiturprüfung), the number of schools where Turkish as foreign language courses are opened decrease every passing year. There is no numerical data about the students taking this course.

\section{First Language Education, and the Turkish Language and Culture Course}

In Federal Germany, there are approximately 580,000 children of Turkish origin. In this context, there are 503 teachers who work under the Turkish consulates. As of the 2016/2017 academic year, around 100,800 students attend Turkish as a first language courses in Germany, and this figure corresponds to $17.3 \%$ of the total number of Turkish-origin children. Of these students, nearly 37,400 students attend the Turkish courses delivered by the teachers working in Turkish consulates, and this corresponds to nearly $6.4 \%$ of Turkish-origin children.

The Standing Conference of the Ministers of Education and Cultural Affairs of the Länder in the Federal Republic of Germany [Die Ständige Konferenz der Kultusminister der Länder in der Bundesrepublik Deutschland] decided to take appropriate measures for the education of foreign children in the country with historical decisions taken on 14-15 May 1969 and 3 December 1971. It was aimed that children preserve and develop their first language knowledge, adapt to their own school system when they return to their countries of origin, and preserve their language and identity (Çakır 2019a: 95). In addition, the European Council adopted a recommendation for member countries to take the necessary measures for the first language education of immigrant children in their countries (see Çakır 2001, 2002, 2018).

The number of students taking Turkish courses and the status of these courses in schools, and the regulations that Turkish teachers working in each state must comply with differ across different state systems (Çakır 2016c). In particular, teachers who are sent to Germany by the Turkish Ministry of National Education to teach Turkish Language and Culture course as affiliated with the consulates in their region are expected to be able to cope with different models of application (Çakır \& Y1ldız 2016). This is due to the fact that education and cultural affairs are left to the local ministries of education in the Federal Republic of Germany, which consists of 16 states. Therefore, 
the organization of the courses in each state is different and includes unique practices that are independent from each other.

As of 2021, the Turkish Language and Culture course taught to Turkish people in the states of Baden-Württemberg, Bavaria, Saarland and Schleswig-Holstein are planned and implemented only by the foreign missions of the Republic of Turkey. While all kinds of administrative and financial support are given to this course in the state of Baden Württemberg, Bavaria considers this course as purely the cultural work of the consulates. In the process, local ministries of education also contribute to the activities related to promotion and announcement. In some states, a dual model is applied. Accordingly, Turkish courses are opened by two separate responsible institutions, that is under the responsibility of both consular teachers and state offices for education. These are the federal states of Bremen, Hamburg, Hessen, Berlin and Lower Saxony. In the federal states of North Rhine-Westphalia and RhinelandPalatinate, first/origin language courses are the responsibility of the state administrations.

\begin{tabular}{|c|c|c|c|c|}
\hline Reg & of the Attaché's Office & $\begin{array}{c}\text { Number of Students Taught } \\
\text { by Teachers Assigned by }\end{array}$ & $\begin{array}{c}\text { Number of Students } \\
\text { Taught by } \\
\text { Teachers }\end{array}$ & TOTAL \\
\hline 1. & Berlin & 1,624 & 1,872 & 3,496 \\
\hline 2. & Düsseldorf & 12,414 & --- & 12,414 \\
\hline 3. & Essen & 11,041 & 113 & 11,154 \\
\hline 4. & Köln & 10,510 & --- & 10,510 \\
\hline 5. & Münster & 9,124 & --- & 9,124 \\
\hline 6. & Hamburg & 900 & 1,620 & 2,520 \\
\hline 7. & Hannover & 3,894 & 680 & 4,574 \\
\hline 8. & Karlsruhe & - & 6,602 & 6,749 \\
\hline 9. & Mainz & 6,125 & 473 & 6,598 \\
\hline 10. & Munich & - & 2,442 & 2,442 \\
\hline 11. & Frankfurt & 4,065 & 3,780 & 7,845 \\
\hline & Nurnberg & - & 1,507 & 1,507 \\
\hline 13. & Stuttgart & - & 8,926 & 8,926 \\
\hline & TOTAL & 59,697 & 28,162 & 87,859 \\
\hline
\end{tabular}

Table 7. Distribution of Students Taking Turkish Courses Across Germany (January 2021) ${ }^{6}$

\footnotetext{
${ }^{6}$ Education Office, Turkish Embassy in Berlin.
} 
As is seen in Table 7, the number of students attending the Turkish Language and Culture course taught by teachers assigned by the local authorities is the highest in Düsseldorf, Essen and Cologne, while the number of students attending these classes taught by teachers assigned by the Turkish Ministry of National Education is the highest in Stuttgart, Frankfurt and Karlsruhe. This table has also significance in terms of presenting the cities where Turkish people are centrally populated.

\begin{tabular}{|c|c|c|c|c|c|c|c|c|c|}
\hline \multirow[b]{2}{*}{ State } & \multicolumn{2}{|c|}{ Beginner } & \multicolumn{2}{|c|}{ Elementary } & \multicolumn{2}{|c|}{ Intermediate } & \multicolumn{2}{|c|}{ Advanced } & \multirow[b]{2}{*}{ Total } \\
\hline & $\begin{array}{c}\text { Fema } \\
\text { le }\end{array}$ & Male & $\begin{array}{c}\text { Fema } \\
\text { le }\end{array}$ & Male & $\begin{array}{c}\text { Femal } \\
\text { e }\end{array}$ & Male & Female & Male & \\
\hline Berlin & 100 & 88 & 392 & 391 & 309 & 317 & 153 & 81 & 1831 \\
\hline Essen & 32 & 48 & 0 & 0 & 18 & 11 & 0 & 0 & 109 \\
\hline Frankfurt & 500 & 489 & 858 & 856 & 377 & 342 & 66 & 72 & 3560 \\
\hline Hamburg & 106 & 109 & 349 & 340 & 242 & 224 & 72 & 38 & 1480 \\
\hline Hanover & 99 & 93 & 106 & 100 & 127 & 112 & 23 & 20 & 680 \\
\hline $\begin{array}{l}\text { Karlsruh } \\
\text { e }\end{array}$ & 353 & 392 & 1476 & 1482 & 931 & 882 & 238 & 200 & 5954 \\
\hline Mainz & 19 & 8 & 90 & 103 & 91 & 88 & 21 & 9 & 429 \\
\hline Munich & 145 & 132 & 646 & 641 & 347 & 276 & 80 & 60 & 2327 \\
\hline Stuttgart & 507 & 486 & 2302 & 2293 & 1051 & 957 & 106 & 97 & 7799 \\
\hline Total & 1861 & 1845 & 6219 & 6206 & 3493 & 3209 & 759 & 577 & $\begin{array}{r}24,16 \\
9\end{array}$ \\
\hline
\end{tabular}

Table 8. Number of Students Attending the Courses Organised by the Turkish Ministry of National Education at the Beginning of the 2020-2021 School Year ${ }^{7}$

Taking the Turkish Language and Culture course is not compulsory, and the course must be requested by parents with a petition so that it can be opened. Turkish Language and Culture course is usually held in schools after normal classes (afternoons) or during free hours. A course is opened at the request of 12 students, and the groups generally include students from different grade levels. In practice, classes are held two hours a week, and do not affect promotion to a higher grade and is generally not graded. A brief note that the Turkish Language and Culture course have been taken can be written on students' report card thanks to teachers' cooperation with school administrations in certain states including Bavaria, or a separate "attendance certificate" by the Office of the Educational Attaché can be given to students as an attachment to their report card.

\footnotetext{
${ }^{7}$ Database of the Education Office, Turkish Embassy in Berlin.
} 


\begin{tabular}{|c|c|c|c|c|c|c|c|c|c|}
\hline \multirow{2}{*}{$\begin{array}{l}\text { Age } \\
\text { Group }\end{array}$} & \multicolumn{2}{|l|}{ Beginner } & \multicolumn{2}{|c|}{ Elementary } & \multicolumn{2}{|c|}{ Intermediate } & \multicolumn{2}{|c|}{ Advanced } & \multirow{2}{*}{ Total } \\
\hline & Female & Male & Female & Male & Female & Male & Female & Male & \\
\hline 6 years & 331 & 308 & 318 & 323 & 4 & 1 & 0 & 0 & 1285 \\
\hline 7 years & 767 & 725 & 1271 & 1211 & 20 & 9 & 0 & 1 & 4004 \\
\hline 8 years & 482 & 495 & 1622 & 1634 & 222 & 186 & 6 & 7 & 4654 \\
\hline 9 years & 141 & 156 & 1731 & 1656 & 691 & 593 & 20 & 10 & 4998 \\
\hline $\begin{array}{l}10 \\
\text { years }\end{array}$ & 90 & 104 & 884 & 958 & 752 & 726 & 45 & 37 & 3596 \\
\hline $\begin{array}{l}11 \\
\text { years }\end{array}$ & 30 & 31 & 173 & 190 & 630 & 542 & 76 & 56 & 1728 \\
\hline $\begin{array}{l}12 \\
\text { years }\end{array}$ & 9 & 18 & 120 & 115 & 516 & 511 & 149 & 125 & 1563 \\
\hline $\begin{array}{l}13 \\
\text { years }\end{array}$ & 6 & 5 & 50 & 50 & 392 & 393 & 142 & 123 & 1161 \\
\hline $\begin{array}{l}14 \\
\text { years }\end{array}$ & 3 & 0 & 17 & 37 & 158 & 120 & 170 & 127 & 632 \\
\hline $\begin{array}{l}15 \\
\text { years }\end{array}$ & 2 & 3 & 24 & 22 & 102 & 127 & 151 & 91 & 522 \\
\hline Total & 1861 & 1845 & 6210 & 6196 & 3487 & 3208 & 759 & 577 & 24143 \\
\hline
\end{tabular}

Table 9. Distribution of Students Taking the Turkish Language and Culture Course by Age Across Germany $^{8}$

The Turkish Language and Culture course is taught by experienced teachers of the Turkish Ministry of National Education who are experts in their fields and speak at least one foreign language. These teachers are selected among those who have at least five years of teaching experience in Turkish schools through written and oral examinations, and following a seminar on adaptation to a foreign mission, they are assigned to needed centres by the Inter-Ministerial Joint Cultural Commission (BAOKK).

The reason why the total number of students taught by teachers assigned by the Turkish Ministry of National Education do not add up as presented in in Tables 7, 8 and 9 is that the numbers reflect the situation at the time. The course is elective and has no effect to promotion to a higher grade. It is regarded by local authorities as a cultural activity and by parents as an activity without compulsory attendance. It is delivered through a blended model (i.e. a combination of face-to-face and distance education) due to the COVID-19 global pandemic. Therefore, numerical data do not match.

After the written and oral exam phases by the Ministry of National Education, Turkish language teachers selected among the candidates who are successful in inservice training involving seminars on adaptation to a foreign mission and are assigned

\footnotetext{
${ }^{8}$ Turkish Ministry of National Education Data Processing System, January 2021.
} 
for a maximum of five years, for one year at a time, are paid from the BAOKK budget. Some unseemly labels ascribed to Turkish teachers are unfounded. The examination and research processes conducted for Turkish teachers should be reviewed in terms of the German teachers that the German government send to Turkey, and the asymmetrical relationship between the two countries should be returned to normal, which are issues that both sides need to work on. (s. Çakır/ Yıldız 2016a, 2016b).

\begin{tabular}{|c|c|c|c|c|}
\hline Name of Mission & Date of Starting Service & Teacher & Instructor & $\begin{array}{l}\text { Approximate } \\
\text { Number of } \\
\text { Turkish } \\
\text { People }\end{array}$ \\
\hline $\begin{array}{l}\text { Office of Educational } \\
\text { Attaché in Hannover }\end{array}$ & $01,03,1977$ & 12 & 0 & 265,230 \\
\hline $\begin{array}{l}\text { Office of Educational } \\
\text { Attaché in Köln }\end{array}$ & 1986 & 0 & 2 & 300,000 \\
\hline $\begin{array}{l}\text { Office of Educational } \\
\text { Attaché in Münster }\end{array}$ & $14,12,1985$ & 0 & 0 & 250,000 \\
\hline $\begin{array}{l}\text { Office of Educational } \\
\text { Attaché in Nurnberg }\end{array}$ & $1966(\mathrm{BK})$ & 27 & 3 & 150,000 \\
\hline $\begin{array}{l}\text { Office of Educational } \\
\text { Attaché in Düsseldorf }\end{array}$ & $1977-78 ?$ & 0 & 0 & 300,000 \\
\hline $\begin{array}{l}\text { Office of Educational } \\
\text { Attaché in Stuttgart }\end{array}$ & 1977 & 163 & 1 & 255,000 \\
\hline $\begin{array}{l}\text { Office of Educational } \\
\text { Attaché in Berlin }\end{array}$ & 1952 & 31 & 0 & 250,000 \\
\hline $\begin{array}{l}\text { Office of Educational } \\
\text { Attaché in Mainz }\end{array}$ & 1977 & 14 & 2 & 74,249 \\
\hline $\begin{array}{l}\text { Office of Educational } \\
\text { Attaché in Frankfurt }\end{array}$ & 1972 & 47 & 0 & 373,966 \\
\hline $\begin{array}{l}\text { Office of Educational } \\
\text { Attaché in Karlsruhe }\end{array}$ & 1973 & 119 & 1 & 110,000 \\
\hline $\begin{array}{l}\text { Office of Educational } \\
\text { Attaché in Essen }\end{array}$ & 1986 & 5 & 0 & 280,000 \\
\hline $\begin{array}{l}\text { Office of Educational } \\
\text { Attaché in Hamburg }\end{array}$ & - & 47 & 0 & 148,000 \\
\hline $\begin{array}{l}\text { Office of Educational } \\
\text { Attaché in Munich }\end{array}$ & 1977 & 42 & 1 & 199,215 \\
\hline TOTAL & & 487 & 10 & $2,955,660$ \\
\hline
\end{tabular}

Table 10. The Number of Teachers, Instructors and Citizens Receiving Educational Services Based on the Regions of Educational Attaché's Offices ${ }^{9}$

For the Turkish Language and Culture course, a new syllabus was prepared that is based on international standards defining language proficiency in accordance with the Common European Framework of Reference for Languages structured the same way as European Language Portfolio (ELP) by language teaching experts, and that was

\footnotetext{
${ }^{9}$ Figures provided by the Offices of Educational Attaché affiliated with the Turkish Ministry of National Education.
} 
approved by the Head Council of Education and Morality of the Turkish Ministry of National Education. This syllabus is in use as of the 2018/2019 school year. During the process in which it was prepared, main themes were determined, multilingualism, multiculturalism, different school types and language levels were taken into account, and the views of parents, teachers and students were also considered.

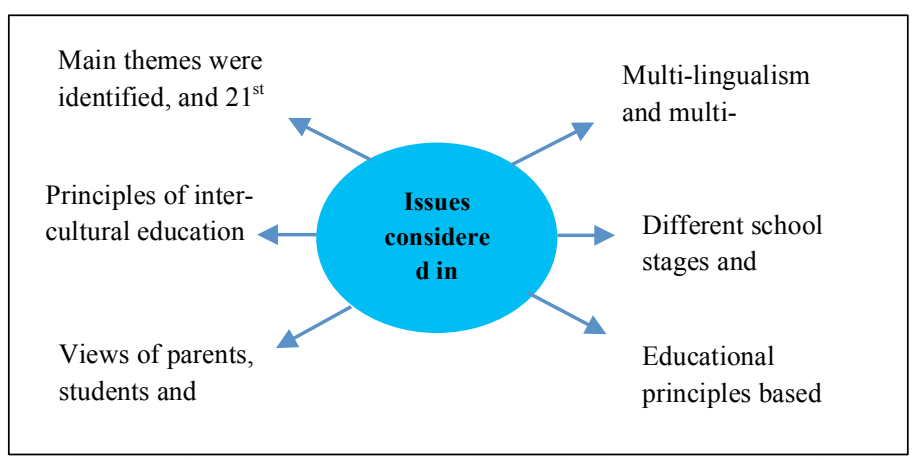

Figure 1. The Development Process of the Turkish Language and Culture Course Syllabus

The new textbooks prepared based on the new syllabus and approved by the Turkish Head Council of Education and Morality were printed 150,000 copies. They started to be used as of the 2018-2019 school year after being distributed for free to all students taking the course via the teachers of the Ministry of National Education. As is foreseen in the syllabus, the textbooks are structured based on international standards defining language proficiency, that is the Common European Framework of Reference for Languages (CEFR) that has same logic as the European Language Portfolio (ELP), and contain student's books and workbooks in eight different levels starting from false or true beginners of Turkish.

The textbooks do not contain false information about Germany in accordance with Article 14 of the Cultural Agreement signed in 1957. The new syllabi, course contents and instructional materials that are also handed over to German counterparts in German, English and French translations can be revised and updated in the meetings of Turkish-German Joint Education Experts (KEUK) that are held every two years.

The Turkish Language and Culture course is taught free of charge in schools that students attend in form of a cultural activity and it is held out of active class hours in the regular class schedule. The course objective is to improve and develop students' communication skills and their ability to use different grammatical structures in speaking and writing. It involves skills activities in areas such as "listening", speaking", "reading", "writing", "grammar" and "knowledge of Turkish geography and history".

Teachers can also create course materials in line with the expected outcomes and pedagogical goals of the course, and classes are conducted with the support of Education Informatics Network (EBA) of the Turkish Ministry of National Education. The purpose of the EBA platform is to support Turkish and Turkish Culture lessons by using information technologies at school, at home; in short, wherever needed, and to 
ensure the efficient use of technology in education. The goal of the EBA platform is to develop and present suitable, reliable and right e-contents appropriate to grade levels. Teachers of the Turkish Language and Culture course are provided in-service trainings on how to use EBA to develop contents and enrich their online classes.

\section{Turkish Courses Offered by the Yunus Emre Institute}

The Yunus Emre Institute continues its activities on teaching Turkish with centres it has opened in many parts of the world within the framework of its mission to enhance the recognition, credibility and reputation of Turkey in the international arena, and it conducts these activities in Germany through its head in Cologne. In Cologne, it opens Turkish as a foreign language courses as well as those courses that aim to introduce and spread the Turkish culture and pass it on to next generations. In addition, Turkish courses are offered to anyone who wants to learn Turkish through its online learning portal (turkce.yee.org.tr) created in 2020 in the headquarters of Yunus Emre Institute in Ankara.

In addition to general Turkish courses, business Turkish, Turkish for young learners, Turkish for tourism, translation workshops and Turkish in the press and media courses are planned and implemented in line with needs and demands. In-service training programs are also organized domestically and abroad for teachers serving in the field, and successful candidates are given a "Certificate of Teaching Turkish as a Foreign Language".

A number of exams for various purposes such as in-service training, certification, placement and Turkish proficiency are administered within the Institute. Within the scope of the Turkish Proficiency Exam held three times a year, certification is offered to people who need it in their education process. These exams are simultaneously available in Turkey and in all countries where the Yunus Emre Institute is located. In this context, the Cologne Centre of Yunus Emre Institute can be accessed via https://koln.yee.org.tr/tr and the events can be followed from this address.

\section{Turkish Language Projects of the Presidency For Turks Abroad And Related Communities}

The Presidency for Turks Abroad and Related Communities (YTB), which is under the Turkish Ministry of Culture and Tourism, mainly carries out its activities focusing on the new generation of Turkish-origin German citizens who has grown up especially after the migration generation in Europe. Activities to create awareness in young people can undoubtedly contribute to Turkish language and culture. In this sense, YTB states various objectives on its corporate website (https://www.ytb.gov.tr/yurtdisivatandans/genel-bilgi). Some of these include the following: 
- To protect and strengthen the ties of our university-age youth, who continue their life and education abroad, with Turkey and Turkish language,

- To increase the participation of our young people who continue their higher education in human rights advocacy and civil society activities with the "Human Rights Training Program",

- To ensure that they have information about the functioning of our institutions with "Turkey Internships",

- To contribute to our young people through educational programs with historical and cultural content, seminars, trips, workshops, vision talks and culture and arts programs, as well as an academic perspective, in the scope of the "Young Leaders" program,

- To strengthen the historical, social and cultural ties of our youth living abroad with Turkey by means of the "Youth Bridges" program.

In addition to its work towards the youth, YTB organises a wide range of activities for children, and carries out projects to collaborate with NGOs. Thanks to this cooperation, the Time for Turkish Project Support Program, the Preschool Bilingual Education Support Program and the Turkish Teacher Training Program for teaching Turkish to children were organised in Europe in general and in Germany in particular. Through NGOs, these projects were opened for application for Turkish citizens living abroad. On the other hand, in the Turkish Teacher Training Program, Turkish-origin teachers who have completed their education abroad receive training in Turkey with a scholarship, and return to their European country after the training. In this context, it is considered important in the context of implementing a work similar to the practice of assigning teachers from abroad by the Turkish Ministry of National Education. Furthermore, YTB has launched a website project (http://ytbcocuk.com) to make children feel close to Turkish language and Culture through digital platforms as they have fun. Detailed information about these projects and applications can be found on the aforementioned websites.

\section{A Future Perspective}

When Turkish language courses offered in Germany are evaluated in terms of efficiency and performance analysis, certain conclusions should be drawn.

In children living and studying in Germany, learning Turkish in addition to their school education primarily contributes to their language development Research studies reveal that the better children speak their first language, the more successful they are in the second language. Bilingualism is an outcome, an additional value for children as well as for the society in which children grow up. However, if this is not accepted and supported by the agents of the dominant culture, problems may arise in children's 
learning not only their own origin-language, but also the second language, that is, the language prevailing in the society and the language of the country in which they live. The awareness that children are expected to develop through bilingualism is inhibited by reasons such as trying to break the connection between children who could not benefit from the outcomes of bilingualism and have been given citizenship from birth with their origin-language, not accepting that they are bilinguals, explicitly or implicitly putting pressure on them because of their bilingual characteristic, and covering up the fact that the origin-language is a prestigious language (Çakır 2000). With children's loss of self-confidence, there is a decline in their school success, leading to undesirable consequences. The obvious indicator of these negative aspects is the statistics showing that a significant number of Turkish (and other foreign/immigrant) students drop out of their general or vocational education without obtaining a diploma. As Günay (2015: 71) states, the reason why students have to start life without completing their education can be that one of the main factors in second language acquisition is the failure to achieve the "cognitive transfer strategy". Children's second language acquisition can be successful as long as it is fed by the first language. It is obvious that the contrary situation may create negative future perspectives for the new generations, which will not be beneficial for the society in which they grow up.

Due to the political attitudes adopted and the educational developments in various states in Germany in recent years, the Turkish Language and Culture course that has been taught in state schools for 50 years is observed to be mostly transferred to the responsibility of German states and to centres of NGOs. In this case, due to the fact that education and training activities have left formal education institutions, the sustainability of the courses disappear, which brings about the danger of not being able to return to formal education institutions. Therefore, it is an inevitable necessity to review the strategies implemented in the classes taught or to be taught by NGOs and to evaluate the gains of these strategies in short and long terms.

With respect to the educational opportunities that taking Turkish classes would provide students, they can choose Turkish as a foreign language instead of English in the graduation exams (i.e. Qualifizierte Mittelschulabschluss) of secondary schools (i.e. Mittelschule), and raise their grade's averages by taking the exam from this language. A high grade average would undoubtedly yield new opportunities for the transition to upper school stages. In addition, if students who attend a vocational high school (i.e. Fachoberschule or Berufsoberschule) certify that they know a second foreign language in the vocational high school graduation exams with a result document from an internationally recognized exam, they are awarded with Abitur (i.e. General High School Graduation Diploma) instead of Fachhochschulreife (i.e. Vocational Higher Education Qualification Diploma). In this way, the knowledge of Turkish language can provide students with a wider choice of university choices. Therefore, students' attendance to the Turkish language course can also create advantages for them in language proficiency exams.

Programs for training Turkish language teachers are not common in Germany. The Department of Turkish Studies (formerly known as Turkish Language Teaching 
Department) at the University of Duisburg-Essen were founded in the Essen province of North Rhine-Westphalia in 1995 to train bilingual Turkish language teacher candidates to teach Turkish-German bilingual children and young people in the secondary school (Sekundarstufe) level. Those who study in this department that started both undergraduate and graduate programs in the scope of the European Higher Education Area and Bologna Process as of 2011-2012 academic year can graduate as TurkishMathematics or Turkish-English teachers. In the 2014/2015 academic year, there were 650 students in the department. There is no numerical data on how many graduates of the department, which had 450 graduates from its establishment in 1995 to 2013, work as Turkish language teachers. As in the example of Munich Ludwig Maximilian University, there seems to be an effort to create secondary disciplines in Turkish language teaching in some departments of Turkology. The best measure to be taken in this regard may be the cooperation of Turkish and German higher education institutions and the development and implementation of dual diploma programs for both training German as a foreign language teachers in Turkey and meeting the need for Turkish language teachers in Germany.

The monolingual structure in German educational institutions should be transformed into a bilingual structure and restructured in terms of the education of bilingual children. It is thus essential that there should be institutional and structural arrangements for children with immigrant backgrounds so that they are provided a comprehensive education in both languages, apart from the non-functional or ineffective language courses that only teach the first and second languages (Çakır 2001). These arrangements may include opening a "Turkish School" in Germany, similar to the German school in Turkey, or a balanced literacy in the two languages, implementing a bilingual education program emphasising the two cultures, and adapting school projects in which education is provided in two different languages like English and French to the Turkish language.

With the origin-language classes (i.e. the Turkish Language and Culture course), it is not likely that Turkish children will properly learn their first language. For this reason, studies can be carried out to further develop the curricula with content that is arranged according to local and regional conditions and is suitable for bilingual learning environments.

As a result, if the reasons behind the problems in academic or diplomatic efforts related to the problems of Turkish citizens abroad are overlooked and the only focus is on the result to provide solutions, it will lead to a vicious circle rather than being sustainable, and new problems will not be prevented in the medium and long term. Moreover, if the waste of energy and resources that serve one-day activities that achieve visibility in the public and popularity for administrators is abandoned, and if the focus is directly on problems and the reasons behind them in accordance with strategic public planning, new and possible problems and diplomatic crises, which are to be encountered in the middle and long term will be more manageable and it will be easier to yield desired outcomes from the efforts invested. 


\section{Acknowledgements}

This study emerged from the study of German-Turkish Relations and Turkish Lessons in Germany on the 60th anniversary of the recruitment agreement signed on October 30, 1961 in Bad Godesberg between the Federal Republic of Germany and Turkey for migration. I would like to thank dear Asst. Prof. Yusuf Öztürk, Head of Department of Foreign Languages at the Faculty of Education, Muş Alparslan University, for the proofreading of this work.

\section{References}

Aksan, Virginia (1997): Savaşta ve Barışta Bir Osmanlı Devlet Adamı: Ahmed Resmi Efendi (17001783), Çev. Özden Arıkan, İstanbul: Tarih Vakfı Yurt Yayınları.

Alba, Richard D.; Handl, Johann; Müller, Walter (1994): Ethnische Ungleichheiten im deutschen Bildungssystem, in: Kölner Zeitschrift für Soziologie und Sozialpsychologie, Jahrgang 46, Heft 2, 209-237.

Alperen, Altan (2018): Viyana Kuşatmalarında Almanya'ya Esir Düşen Türkler. 21. Yüzyılda Eğitim Ve Toplum Ĕ̈itim Bilimleri Ve Sosyal Araştırmalar Dergisi, 7 (20), 623-649. URL: https://dergipark.org.tr/tr/pub/egitimvetoplum/issue/43432/530214.

Altan, Ebru (2003): İkinci Haçlı Seferi (1147-1148). Ankara: TTK Yayınları, VII. Dizi-Say1 211.

Appel, René/ Muysken, Pieter (1987): Language Contact and Bilingualism. New York: Edward Arnold.

Araslı, Alhan Altan (2009): Avrupa'da Türk İzleri, Ankara: Akçağ Yayınları.

Arı, Kemal (1997): Birinci Dünya Savaşı Kronolojisi. Ankara: Genelkurmay Basımevi.

Aslan, Ahmet (2020): İki Dillilik ve Çok Dillilik Nedir? İçinde: Perspektif Dergisi. 14 Kasım 2020. https://perspektif.eu/2020/11/14/iki-dillilik-ve-cok-dillilik-nedir/ (14.03.2021)

Ateşal, Zeynep (2017): İki Dillilik ve Çift Dil. Uluslararası Sosyal Bilimler Dergisi. 1/2017, 7. 1-12.

Auswärtiges Amt (2018): Işste Almanya: Dış politika, Toplum, Bilim, Ekonomi, Kültür. Frankfurt am Main: FAZIT Communication GmbH. URL: https://www.tatsachen-ueberdeutschland.de/files/2020-11/tatsachen_2018_tur-compressed.pdf (Son erişim: 28.02.2021).

Bernhard, Armin (2012): Alman Eğitim Sistemi ve Göçmenlerin Fırsat Eşitliği. Die Gaste, Sayı: 24 / Kasım-Aralık 2012.

Bacınoğlu, Tamer/ Bacınoğlu, Andrea (2001): Modern Alman Orientalizmi: Alman Yayıncılı̆̆ının Türkiye Tablosu. Ankara: Asam Yayınları 24.

Bayur, Yusuf Hikmet (1983): Türk Inkılabı Tarihi. C. III, Kısım I. Ankara: TTK Yayınları.

Bekar, Beytullah (2016): İki Dilliliğin Çeşitleri ve Ana Dili Edinimi Açısından Değerlendirilmesi (Almanya Türkleri Özelinde). Mehmet Ölmez (Ed.). Uluslararası Yulduz Türk Dili Sempozyumu 25Nisan 2016 Bildiriler Bilge Su Yayınları.

Bekar, Beytullah (2015): Almanya Türkçesi, Erciyes Üniversitesi Sosyal Bilimler Enstitüsü, Kayseri (Basılmamış Doktora Tezi).

Borchmeyer, Dieter (2017): Was ist Deutsch? Die Suche einer Nation Nach Sich Selbst. 2. Bask1, Berlin: Rohwolt. 
Bölükbaş Kaya, Fatma vd. (2019): İki Dillilik: Tanımı ve Türleri Üzerine Kuramsal Tartışmalar. International Journal of Languages' Education and Teaching. 7/2, 98-113.

Büchel, Felix/ Wagner, Gert (1996): Soziale Differenzen der Bildungschancen in Westdeutschland Unter besonderer Berücksichtigung von Zuwandererkindern, in: Zapf, Wolfgang/Habich, Roland/Schupp, Jürgen (Hg.): Lebenslagen im Wandel. Sozialberichterstattung im Längsschnitt, Frankfurt/New York: Campus, 80-96.

Chomsky, Noam (2018): Dil ve Zihin. (Transl. Ahmet Kocaman) 3. Basım. Ankara: Bilgesu Yayıncılık.

Clyne, Michael (1968): "Zum Pidgin-Deutsch der Gastarbeiter". Zeitschrift für Mundartforschung 35, 130-139.

Cummins, James (1982): Die Schwellenniveau- und Interdependenz-Hypothese: Erklärungen zum Erfolg zweisprachiger Erziehung. In: Swift, James (Yay.): Bilinguale und multikulturelle Erziehung. Würzburg: Königshausen + Neumann, 34-43.

Çakır, Mustafa (1991): Identifikationsprobleme der ausländischen bzw. türkischen Arbeitnehmer im deutschsprachigen Raum. Österreichisch Türkische Beziehungen aus sozio-kultureller Sicht: Beiträge der Österreich-Woche an der Anadolu Universität Eskişehir (5-8 Juni 1990), Eskişehir: Anadolu Ün. Ya.No: 543, $54-58$.

Çakır, Mustafa (2000): Almanya'daki Türk çocuklarının interkültürel etkileşime dayalı sorunları ve çözüm önerileri. Anadolu Üniversitesi Ĕ̆itim Fakültesi Dergisi, 2000, Cilt: 10, Say1: 1, 133-142.

Çakır, Mustafa (2001): Almanya'daki Türk Çocuklarının Okulöncesi Eğitim Sürecinde Almancayı İkinci Dil Olarak Edinmelerini Etkileyen Olgular. TÖMER Dil Dergisi. Say1: 107, Ekim 2001, 34-43.

Çakır, Mustafa (2001): Göçün Kırkıcı Yılında Almancanın İkici Dil Olarak Edinimini Etkileyen Kültürlerarası Olgular. Köln: Ultima Ratio Dizisi 01, 2001.

Çakır, Mustafa (2002): Almanya'daki Çok Kültürlü Ortamlarda Türkçenin Anadili Olarak Kullanımı. Anadolu Üniversitesi Sosyal Bilimler Dergisi. Cilt: 2, Say1: 1, 2002, 39-57.

Çakır, Mustafa (2012): Türklerin Alman Kültüründeki İmajı. Zehra Gülmüş (Ed.). Türk Alman İşgücü Anlaşması'nın 50.Yılında Almanya Türkleri. Eskişehir: Anadolu Üniversitesi Yayınları Yayın No: 2581, Yurtdışında Yaşayan Vatandaşların Sorunlarını Araştırma Merkezi Yayınları Yayın No: 3, 27-52.

Çakır, Mustafa (2014): Die Förderung der Herkunftssprache von türkischstämmigen Kindern in Deutschland. Anadolu Üniversitesi Sosyal Bilimler Dergisi Ĕgitim Fakültesi 30. Yıl Özel Saylsl. 2014, 155-166.

Çakır, Mustafa (2015): Türkiye'de Almancı Almanya'da Yabancı Olan Türkler. Türk Yurdu: Yerel Süreli Yayın. 7. Devre, Cilt 35 (67), Say1 338 (699), 104. Y1l (10.10.2015), 60-71.

Çakır, Mustafa/ Yıldız, Cemal (2016): Almanya'daki Türk Öğretmenlerin Bu Ülkede Verdikleri Türkçe ve Türk Kültürü Dersinin Uygulanmasına İlişkin Görüşleri ve Karşılaştıkları Sorunlar. Alpaslan Okur, Bekir İnci, İsmail Güleç (Eds.) Yabancılara Türkçe Öğretimi Üzerine Araştırmalar: 2. Uluslararası Türkçenin Yabancı Dil Olarak Öğretimi Kongresi 20-21 Mayıs 2016 Almanya. Sakarya: Üniversitesi Türk Dili Öğretimi Uygulama ve Araştırma Merkezi Yayınları, s. 27-36. (ISBN: 978-605-4735-82-2) URL: http://www.tomer.sakarya.edu.tr/upload/yayinlar/2.pdf (24.11.2016).

Çakır, Mustafa/ Yıldız, Cemal (2016a): Almanya'daki Türk Öğretmenlerin Türkçe ve Türk Kültürü Dersine İlişkin Görüşleri. İçinde: International Journal of Languages' Education and Teaching (IJLET). 4/2, 217-257. Doi: http://dx.doi.org/10.18298/ijlet.627. (04.01.2017).

Çakır, Mustafa/ Yıldız, Cemal (2016b): Aktueller Bildungs- und Erfolgsstand der türkischen und türkischstämmigen Schüler in Deutschland. Güven Günaltay (Yay.). Bildung und interkultureller 
Dialog: Kurzbeiträge für Lehrkräfte/Ĕ̆itim ve Kültürlerarası Diyalog: Öğretmenler İçin Klsa Makaleler. Berlin: BAU International Berlin-University of Applied Sciences, 61-72.

Çakır, Mustafa (2016c): Çok Kültürlü Ortamlardaki Çocuklara Türkçe Öğretimi ve Bireysel İki Dillilik. İçinde: Alpaslan Okur, Ismail Güleç (Yay.). III. Avrupalı Türkler Anadili Egitimi Çalıstayı. 20-21 Mayıs 2016 Münih-Almanya. Sakarya Üniversitesi Türk Dili Öğretimi Uygulama ve Araştırma Merkezi Yayınları. Sakarya: 2016, 67-103. ISBN: 978-605-4735-83-9 URL: http://www.tomer.sakarya.edu.tr/upload/yayinlar/1.pdf (24.11.2016).

Çakır, Mustafa (2018): Yurt Dışında Anadili Dersinin Önemi. Filiz Şan, Elif Akkan (Ed.): Prof. Dr. İlyas ÖZTÜRK'e Armă̆an - Kültürlerarası Çalışmalar (Festschrift für Prof. Dr. Ilyas ÖZTÜRK Interkulturelle Beiträge), 1. Basım, Sakarya: Sakarya Üniversitesi Yayını, 349-354.

Çakır, Mustafa (2019a): Güney Bavyera’daki Türkçe Anadili Dersi ve Türkçe Öğretmenleriyle İlgili Paradigmatik Bir Değerlendirme. Toplum Bilimleri Dergisi-Journal of Social Sciences. Haziran / June20019, 25: 89-120. Makale Bilgisi / Article Information http://dx.doi.org/10.29228/tbd.2007.25.1427.

Çakır, Mustafa (2019b): "A Critical Analysis to the Issues of the Turkish classes in Bavaria" International Journal of Social Policy and Education. Vol. 1. No. 2, December 2019, ss. 1-6, ISSN 2689-4998 (print), ISSN 2689-5013 (online), https://ijspe.com/wpcontent/uploads/2019/12/1.pdf (son erişim: 14.03.2021).

Çolak, Mustafa (2014): Alman Imparatorluğu’nun Doğu Siyaseti Çerçevesinde Kafkasya Politikası (1914-1918), 2. Bask1. Ankara: Türk Tarih Kurumu Yayını.

Esser, Hartmut (2006): Sprache und Integration. Die sozialen Bedingungen und Folgen des Spracherwerbs von Migranten, Frankfurt a. Main/New York: Campus Verlag.

Estel, Bernd (1993): Nation und nationale Identität. Hagen: FernUniversität.

Fthenakis, Wassilios E. etc (1985): Bilingual-bikulturelle Entwicklung des Kindes. 1. Bask1. München: Max Hueber Verlag.

Gencer, Mustafa (2002): Bildungspolitik, Modernisierung und kulturelle Interaktion Deutsch - türkische Beziehungen (1908-1918). Münster-Hamburg-Berlin-Wien-London: LIT Verlag. (Konfrontation und Kooperation im Vorderen Orient Bd. 8.

Genç, Safiye (2011): Sprachökonomie im Bilingualismus (Deutsch - Türkisch) und ihre möglichen Erscheinungen im Sprachgebrauch. (Unpublished doctoral thesis). İstanbul Üniv. Sos. Bil. Ens. İstanbul.

Glabonıat, Manuela/ Müller, Martin / Rusch, Paul/ Schmitz, Helen/Wertenschlag, Lukas (2013): Profile deutsch: Lernzielbestimmungen, Kannbeschreibungen und kommunikative Mittel für die Niveaustufen A1, A2, B1, B2, C1 und C2 des "Gemeinsamen europäischen Referenzrahmens für Sprachen" München: Klett Sprachen.

Gogolin, Ingrid (1995): Sprache und Migration. Hansen, Georg/Schmalz-Jacobsen, Cornelia (Hrsg.): Ethnische Minderheiten in der Bundesrepublik Deutschland. Ein Lexikon. München: Beck, 481490.

Günay, Doğan V. (2015): İki ya da Çok Dillilik ve Avrupa Toplumu. Turkophone, 2 (1), 68-72. URL: https://dergipark.org.tr/en/pub/turkophone/issue/18995/200501 (Son erişim: 15.03.2021).

Güzel, Abdurrahman/ Barın, Erol (2013). Yabancı Dil Olarak Türkçe Öğretimi (1. bs.). Ankara: Akçăg.

Heidelberger Forschungsprojekt „Pidgin-Deutsch“ (1975): Sprache und Kommunikation ausländischer Arbeiter. Kronberg/Ts: Scriptor. 
Haznedar, Belma (2021): İkidillilik ve Çokdillilik Erken Çocukluk Döneminde Birden Fazla Dil Öğrenimi. Ankara: Anı Yayıncılık.

Hopf, Diether (1981): Die Schulprobleme der Ausländerkinder, Zeitschrift für Pädagogik 27/6, 839-861.

Karaağaç, Günay (2011): Bireysel İki Dillilik ve Toplumsal İki Dillilik, Türk Dili, C I, S. 717, Eylül 2011, 222-228.

Kaya, Ayhan (2000): Berlin'deki Küçük İstanbul. İstanbul: Büke Yayınları.

Keim, Inken (1978): Gastarbeiterdeutsch. Untersuchungen zum sprachlichen Verhalten türkischer Gastarbeiter. Forschungsberichte des Instituts für deutsche Sprache. Bd. 41. Tübingen: Narr.

Keim, Inkem (1981): Das Deutsch türkischer Gastarbeiter. Untersuchungen zum ungesteuerten Spracherwerb. (masch. Diss. Mannheim). Mannheim.

Keim, Inken (1984): Untersuchungen zum Deutsch türkischer Arbeiter. Tübingen: Narr, (Forschungsberichte des Instituts für Deutsche Sprache Mannheim; Bd. 50).

Klein, Wolfgang (1992): Zweitsprachenerwerb. Studienbuch Linguistik. Frankfurt am Main: Athenäum Verlag, ISBN: 9783445030580

Koçak, Cemil (1991): Türk-Alman İlişkileri (1923-1939), Ankara: Atatürk Kültür Dil ve Tarih Yüksek Kurumu. Türk Tarih Kurumu Yayınları: XVI. Dizi, 66.

Koçtürk, Milazım (2008): Almanya’ya Göçün Tarihi. Die Gaste, SAYI: 2 / Temmuz-Ağustos 2008. URL: http://www.diegaste.de/gaste/diegaste-sayi210.html (Son erişim: 02.03.2021).

Krashen, Stephen (2002): Second Language Acquisition and Second Language Learning. California, Pergamon Press.

Krashen, Stephen (1982): Principles and Practice in Second Language Acquisition. Oxford: Pergamon Press.

Krashen, Stephen/ Terrell, Tracy D. (1983): The Natural Approach. Language Acquisition in the Classroom. London: Prentice Hall.

Meisel, Jürgen (1975): Der Erwerb des Deutschen durch ausländische Arbeiter. Untersuchungen am Beispiel von Arbeitern aus Italien, Spanien und Portugal. Linguistische Berichte 38, 59-69.

Muhtar, Mahmut (1999): Maziye Bir Nazar: Berlin Anlaşmasından I. Dünya Savaşına Kadar Avrupa ve Türkiye-Almanya Münasebetleri. (Transl. Erol Kılınç). Ankara: Ötüken Neşriyat.

Önder, Mehmet (1983): Yurt Dlşı Müzelerinde Türk Eserleri. Ankara: Kültür ve Turizm Bakanlığı No: 533, Sanat Eserleri Dizisi, No: 3.

Özakıncı, Cengiz (2007): Türkiye'nin Siyasi İntiharl 'Yeni-Osmanll' Tuzağl: Osmanlı'dan Günümüze Din Üzerinden Emperyalist Oyunlar. 2. Bask1 (1. Bask1 2005), İstanbul: Otopsi Yayınlar1.

Özbal, Bayram (2020): Osmanlıdan Günümüze Almanlar İçin Hazırlanmış Yabancı Dil Olarak Türkçe Kitapları: Bir Kaynakça Denemesi. International Journal of Language Academy 31(31),180-195. DOI: $10.29228 /$ ijla.40261.

Öztuna, Yılmaz (1996): Devletler ve Hanedenlar, 2. Baskı. Cilt IV. Ankara: Kültür Bakanlığı.

Öztürk, Ali Osman (2000): Alman Oryantalizmi: 19. Yüzyll Alman Halk Kültüründe Türk Motifi. Ankara: Vadi Yayınları.

Quetz, Jürgen (2010): Der Gemeinsame europäische Referenzrahmen (GER) als Grundlage für Sprachprüfungen - Eine kritische Beschreibung des Status quo. In: Deutsch als Fremdsprache, 47. Jg., H. 4, 195-202.

Reiser, Helga R. (Hg.) (1981): Sonderschulen - Schulen für Ausländerkinder?, Berlin: Carl Marhold Verlagsbuchhandlung. 
Reiss, Kristina (Ed.) (2019): PISA 2018. Grundbildung im internationalen Vergleich. Münster, New York: Waxmann, E-Book ISBN 978-8309-9100-7 Doi: https://doi.org/10.31244/9783830991007.

Rolffs, Songül (2009): Yine İki Dillilik Üzerine. Die Gaste, Sayı: 5 / Ocak-Şubat 2009. URL: http://www.diegaste.de/gaste/diegaste-sayi506.html (Son erişim: 12.03.2021).

Schwenk, Helga (1988): Das Sprachvermögen Zweisprachiger türkischer Schüler, Tübingen: Gunter Narr Verlag.

Siegert, Manuel (2008): Schulische Bildung von Migranten in Deutschland. Working Paper 13 der Forschungsgruppe des Bundesamtes aus der Reihe "Integrationsreport" Teil 1. https://www.bamf.de/SharedDocs/Anlagen/DE/Forschung/WorkingPapers/wp13-schulischebildung.pdf?_blob=publicationFile\&v=11 (son erişim: 06.03.2021).

Tuna, Orhan (2011): Türkiye'den Federal Almanya'ya İşgücü Akımı ve Meseleleri . İstanbul Üniversitesi İktisat Fakültesi Mecmuas1, 24 (1-2), 3-43. URL: https://dergipark.org.tr/tr/pub/iuifm/issue/819/8932 (Son erişim: 02.03.2021).

Uyar, Gülşen (2012): İkidillilik (Bilingualism). Dilim. Ankara Üniversitesi Dilbilim Topluluğu Dergisi, 9, 21-25.

Ünver, O. Can (2015): Alman Kışı: Neo-Liberal Çağın Almanya'sında Irkçılığın Hedefindeki Göçmenler. Ankara: Nika Yayınevi.

Weinreich, Uriel (1968): Languages in contact: Findings and problems. Paris, Mouton: The Hague.

Yıldırım, Mustafa (2008): Tarihten Günümüze Münih’teki Türkler ve Bazı Türk Eserleri. Selçuk Üniversitesi Sosyal Bilimler Enstitüsü Dergisi. Say1: 19. 489-506 URL: http://dergisosyalbil.selcuk.edu.tr/susbed/article/view/430 (02.03.2021).

Yıldız, Cemal (2003): Ana dili Öğretiminin Temel İlkelerine Karşılaştırmalı Bir Bakış (Türkçe ve Almanca Ana dili Öğretimi Programları Örneğinde). Dil Dergisi, Say1. 120, 5-21.

Yılmaz, Mehmet Yalçın (2014): İki Dillilik Olgusu ve Almanya’daki Türklerin İki Dilli Eğitim Sorunu. Turkish Studies - International Periodical For The Languages, Literature and History of Turkish or Turkic. Volume 9/3 Winter 2014, 1641-1651. 